\title{
Faith in African Lived Christianity - Bridging Anthropological and Theological Perspectives: Introduction
}

\author{
Mika Vähäkangas and Karen Lauterbach
}

What is the role of faith in African lived Christianity and what roles do faith and religious experiences play in the ways that people understand and explain social realities in Africa? This book discusses these two overarching questions, particularly their relatedness, by bringing theology and anthropology into dialogue in the study of African Christianity. Studying the significance and transformation of Christianity in Africa calls for an understanding of faith that is sensitive to the local context in which faith is lived and experienced. By overcoming the historic dividing line between theology and anthropology in the study of African Christianity, the book seeks to build interpretative bridges between African enchanted worldviews and analytical concepts often founded in Western academic traditions. In this way, the book does not question people's faith or try to understand why they have faith. ${ }^{1}$ It takes faith as the starting point and explores how this influences people's engagement with the world. The book contributes to an emerging literature that combines analysis of religious experience and faith with analysis of how religion feeds into social ideas and practices.

The study of faith in African lived Christianity requires an open and broad interdisciplinary approach. African Christians often locate themselves in an interreligious field in which African pre-Christian traditions as well as Islam co-exist with Christianity. This locus of religious plurality is at times perceived as a field of tension, not only between religious traditions, but also within the world of African Christianity. There is ongoing negotiation and competition between the values and truth-claims in these contexts which are not only a matter of different and competing traditions; it is also a matter of how one reads the world through a religious lens and how social reality informs religious ideas and values.

1 See the contribution by Tanya Luhrmann in Brian Howell et al., "Faith in Anthropology: A Symposium on Timothy Larsen's The Slain God," The Cambridge Journal of Anthropology 34, no. 2 (2016): 140-152. 
Historically there has not been much dialogue between anthropology and theology as classical academic disciplines. This might seem surprising as both focus on the experiences of human beings by studying traditions, rituals, ideas, faith, and artefacts. Despite these similarities, however, there are fundamental differences between them, which, as Davies points out, relate in particular to whether or not the existence of God can be assumed. ${ }^{2}$ In the past, many theologians saw anthropology as irrelevant, dealing as it did with exotic cultures which had little or no pertinence to academic theological study. Western Christian theology was about studying biblical texts and the history of Christianity and had little interest in the experiences of believers themselves. Theologians' lack of dialogue with anthropology was also due to Christianity's not being perceived as a topic worthy of study by many early (and later) anthropologists. This antagonism, however, reveals an indirect influence of theology on anthropology: it is not only what you agree with but also what you reject that defines your agenda. For example, both E.B. Tylor and James Frazer had conservative Christian family backgrounds, and their academic agenda was partly defined by rejection of that. ${ }^{3}$

Prior to the Second World War, a major exception in the almost active ignorance of foreign cultures that characterized theology were mission scholars, who were often enlightened and attracted by anthropological studies of the foreign places in which they were working. Ethnographic approaches to studying the mission fields were especially popular among the missionaries. However, this love was relatively one-sided because the quintessential classical anthropologist despised the missionaries as much as he was dependent on them, as the missionaries provided much of the empirical data on which he relied. The missionaries belonged to the same group of functionaries as the colonialists, who were destroying authentic cultures around the world by imposing Western values and structures. Yet, at the same time, missionaries were frequently present and familiar with local vernaculars on the anthropologists' arrival in destinations of interest, and therefore very useful for the latter's work. It is telling, however, that missionaries and churches are hardly visible in classical anthropology, even in cases where they obviously had presence and effect. Christian mission was written out of anthropology, and mission scholars studying it, traditionally in a rather confessional and uncritical manner, were not potential academic partners. However, among British anthropologists, those with personal Christian (often Roman Catholic) conviction, especially

2 Douglas Davies, Anthropology and Theology (Oxford \& New York: Berg, 2002).

3 Timothy Larsen, The Slain God: Anthropologists and the Christian Faith (Oxford: Oxford University Press, 2014). 
E.E. Evans-Pritchard, would differ from this pattern and portray missionaries in their works. ${ }^{4}$

Moreover, anthropological studies of Christianity in Africa had a focus on the Africanization of missionary forms of Christianity and studied mostly African Independent Churches. This focus highlights a culturalist interpretation of Christianity in Africa in which the cultural adaptation of Christianity is privileged, and the role of Christian missionaries downplayed. The French anthropologist and sociologist, George Balandier, for instance, wrote on Messianic movements in French Congo such as Kimbanguism. ${ }^{5}$ Another, more recent, example of anthropological work on Christianity in Africa is Jean-Pierre Dozon's work on prophetism, again focusing on syncretic aspects of African Christianity. ${ }^{6}$ As Harris and Maxwell point out, the scholarly focus on prophets and leaders of the African Independent Churches echoes a focus on African political leaders who fought for independence and symbolized resistance to Western dominance. ${ }^{7}$

Subsequently, applied anthropology was used both in the spheres of colonial administration and Christian missions, which meant that dialogue increased between the two disciplines. Missiology, which was at the time a purely confessional discipline, used anthropology in a rather instrumental way to serve its interests, and was embraced both by Catholics ${ }^{8}$ and Evangelicals. Much of the Evangelical research in missiological anthropology revolved around the journal Practical Anthropology ${ }^{9}$ and places like Wheaton College (Illinois) and Fuller Seminary (California). Colonial administrators found anthropology a useful tool with which to gain a more solid grip on the local populations by knowing them better, while in missiological anthropology the goal was often to get to know the cultures in order to be more efficient at converting people. Anthropologists naturally viewed this as a usurpation of

4 Ibid., 103-105, 129.

5 George Balandier, "Messianismes et Nationalismes en Afrique Noire," Cahiers Internationaux de Sociologie 14 (1953): 41-65.

6 Jean-Pierre Dozon, La cause des prophètes: politique et religion en Afrique contemporaine (Paris: Seuil, 1995).

7 Patrick Harris and David Maxwell, "Introduction: The Spiritual in the Secular," in The Spiritual in the Secular: Missionaries and Knowledge about Africa eds. Patrick Harris and David Maxwell (Grand Rapids, Michigan: William B. Eerdmans Publishing Company, 2012), 2.

8 One of the most extensive Catholic missiological anthropologies is provided by Louis Luzbetak, The Church and Cultures: New Perspectives in Missiological Anthropology (Maryknoll, NY: Orbis Books, 1989).

9 Darell Whiteman, "One Significant Solution: How Anthropology Became the Number One Study for Evangelical Missionaries, Part II: Anthropology and Mission: The Incarnational Connection," International Journal of Frontier Missions 21, no. 2 (2004): 79-80. 
anthropological tools in the service of goals and values diametrically opposed to the basic values of the discipline. In the same way, the work and influence of missionaries has been largely ignored in Africanist historiography as missionaries were seen as cultural imperialists who should not be the focus of scholarly attention. ${ }^{10}$ In practice, however, the borders between theology and anthropology were not fully water-tight because there were colonial administrators and missionaries who engaged in ethnographic work out of fascination with the local cultures, while there were anthropologists fully trained in the discipline joining the ranks of colonial administrations.

Since the pre-Second World War period, much has happened. Overt colonial structures have been dismantled, and Christian mission is carried out increasingly by local actors or by missionaries coming from non-Western countries. Anthropologists have, to a greater degree, acknowledged the existence of Christianity as part of their field of study, and the emergence of the anthropology of Christianity as a better-defined branch of the discipline has further enhanced this focus and has strengthened theoretical debates in the field. Meanwhile, some mission scholars have begun to critique and distance themselves from the Western missionary heritage, and that research is carried out increasingly by scholars from the Global South. ${ }^{11}$ There are also signs that theology as a discipline is gradually waking up to the major shift of gravity of Christianity from the West to the Global South. It is no longer only the mission scholars among theologians who recognize and cherish the variety of cultures and interpretations of Christianity. All this has prepared the ground for a beneficial interchange between anthropology and theology.

The development of the anthropology of Christianity and its subsequent growth led some anthropologists to consider the advantages of a closer dialogue with theology. At the same time though, the perceived differences in basic values and goals were a concern. Theology probably appears a more unified discipline from the outside than theologians themselves consider the case. The values and goals depend largely on the way the Bible is approached, and there the variation is great: from fundamentalism to strictly rationalistic, historical-critical approaches or consciously pluralist readings. Anthropologists of Christianity began their studies with a heavy emphasis on Charismatic and Pentecostal Christianities in the Global South, which inevitably affected

$10 \quad$ Harris and Maxwell, "Introduction."

11 E.g. Kwame Bediako, Theology and Identity: The Impact of Culture upon Christian Thought in the Second Century and in Modern Africa (Oxford: Regnum Books International, 1992); Jehu Hanciles, Beyond Christendom: Globalization, African Migration, and the Transformation of the West (Maryknoll, NY: Orbis Books, 2008); Veikko Munyika, A Holistic Soteriology in an African Context (Pietermaritzburg: Cluster Publications, 2004). 
their views on theology, too. When Christianity and ways of theologizing that were most familiar to these anthropologists were non-Western forms of Charismatic Christianity, even theology in general appeared in stark contrast to Western Enlightenment ideals. As Western academic theology, especially in its liberal form, has been in dialogue with the Enlightenment since its very beginning, it is often in radical discontinuity with the charismatic currents of approaches in the Global South.

In this volume, we consider Christian theology to be any meaning-making of Christian faith. The implication of this is, in practice, that theology can be both academic and ecclesiastic, the latter partly being at the grass-roots. In all cases the meaning-making happens in relation to Christian traditions. This relation can be affirmative or critical and even lead to complete rejection of the central tenets of Christian faith. Inasmuch as the rejection is specifically of Christian faith, even that belongs to the sphere of Christian theology due to its affiliation with the Christian traditions. What makes theology academic is its critical, self-critical and open-ended nature combined with methodological stringency. Academic theology differs from the rest of the academic study of African Christianity in the sense that it engages with the object of study in two inclusive manners. On the one hand, the agenda of the studied theology is respected and the focus is on the contents of the meaning-making rather than on the social circumstances or external ways of interpreting the faith. The analysis happens as if inside the studied thought world (system immanence). On the other hand, a theologian can be a marginal insider in a way differing from the anthropologist. She can relate to the meaning-making of the studied community with her personal meaning-making and enter in a dialogue which can sometimes be critical. In spite of this seemingly neat distinction between theology and other approaches to religion, theology and other approaches to religion are not as distinguishable in practice. This is partly due to the increasing realization among theologians studying African Christianity, among others, that theological meaning-making is not exclusively cerebral. This insight is strongest among majority world theologians. ${ }^{12}$ This has led theologians to adopt various empirical approaches to lived religion in addition to the previously dominant textual approaches. Another reason for this decreasing

12 Emma Wild-Wood, "Afterword: Relocating Unity and Theology in the Study of World Christianity," in eds. Joel Cabrita, David Maxwell and Emma Wild-Wood Relocating World Christianity: Interdisciplinary Studies in Universal and Local Expressions of the Christian Faith (Leiden: Brill, 2017), 338-339. 
rift between theology and the rest of study of religion is that there are streams in other disciplines that assume approaches resembling theology. ${ }^{13}$

In this volume, following the insight that meaning-making of Christian faith is not only a cerebral matter, and in addition that even much of cerebral meaning-making happens in the ritual practice, we see theology larger than only systematic or philosophical theology. That is one of the reasons for deciding to approach the relationship between theology and anthropology through lived religion.

Generally speaking, the more liberal and pluralistic a theologian is, the less interested she is in Christian expansion and thereby in World Christianity as a field of study. This probably stems from two factors. A liberal theologian finds less in common with Christianity in the Global South than a conservative theologian and in theology one tends to be pulled to study the same rather than the other, in contrast to classical anthropology. Additionally, all research is related to the ideological positions of the researchers in different ways. In theology, this connection is often very direct and visible. The theological liberal-conservative tug of war is basically about how to relate the Bible and the Enlightenment. The liberal theological way of reading the Bible through the Enlightenment does not find much resonance in the Global South, while conservative Western theologians seek allies there, often glossing over the differences between Western conservative theologies and Southern interpretations of Christianity. This encourages a wide but not very profound study of the Christianities of the Global South in order to find support while ignoring the differences. Thus, liberal theologians who are more likely to be closest to the anthropologists' basic values are, on average, those least interested in the anthropologists' fields of study.

Anthropology does not only provide theologians with ethnographic tools with which to embark on empirical approaches to studying Christianity, but also with theoretical insights onto particular cultural themes and a welldeveloped discussion on how to deal with data from foreign cultures in a manner that respects human, cultural, and religious plurality. Theology, in its turn, can provide anthropologists with detailed insights about the history and development of different religious ideas and the interconnections between them, how Christians perceive their religious identity, and how to engage with the existential dimensions of religion. Explorations of mutually beneficial

13 See for instance Jorge N. Ferrer and Jacob H. Sherman, "Introduction," in The Participatory Turn: Spirituality, Mysticism, Religious Studies eds. Jorge N. Ferrer and Jacob H. Sherman (Albany, NY: SUNY Press, 2008), 1-80; The Australian Journal of Anthropology (2013) 24/3 was a special issue dedicated to theology in anthropology. 
cooperation between the two disciplines are not completely novel. Anthropologists with Christian conviction led to the emergence of the first wave of deeper interchange between anthropology and theology. One dimension of it occurred within anthropological works in which Christian theology was used as a point of comparison or to help in clarification, like in Evans-Pritchard's Nuer Religion. ${ }^{14}$ Another marginal connection between the disciplines occurred through anthropologists' comparative endeavors, which sometimes included Christian cultures..$^{15}$ The most substantial connection, however, took place when a few anthropologists, most notably Mary Douglas, contributed directly to theological research. In the case of Douglas, the most obvious contribution was in Biblical Studies. ${ }^{16}$

Because of the long and oftentimes troubled relationship between the disciplines, there have not been interdisciplinary joint ventures of a larger scale. Today, there seem to be possibilities to move in that direction for several reasons. In theology, the Christian confessional approach is no longer the only norm; rather, there is a range of new approaches including interreligious, comparative, empirical, and postfoundational theologies, among others. Thus, the anthropological tendency towards cultural relativism is not such anathema for all theologians as it used to be. At the same time, the ideological outlook of anthropology has become more accommodating to faith-based approaches. Thus, both disciplines have opened up ideologically, making it easier to find common ground.

In Britain, there are a number of scholars and platforms bringing these two fields together. Martin D. Stringer, for example, could be described as a theologically informed anthropologist who has studied Christianity from an anthropological perspective. He differs from the majority of anthropologists of Christianity in the sense that he has been studying it in his own cultural context. Durham University has created a center where these two fields meet: the Durham professor, Douglas Davies, started as an anthropologist of religion, later entering the field of theology, and the two disciplines merge in his career and publications. ${ }^{17}$ Mathew Guest continues that tradition; while Durham also hosts the Network for Ecclesiology and Ethnography led by Pete Ward. In all of the above, the emphasis has largely been on Western forms of Christianity and

14 E.E. Evans-Pritchard, Nuer Religion (Oxford: Oxford University Press, 1956); Larsen, The Slain God, 107-109.

15 Larsen, The Slain God.

16 Mary Douglas, In the Wilderness: The Doctrine of Defilement in the Book of Numbers (Sheffield: Sheffield Academic Press, 1993); Mary Douglas, Leviticus as Literature (Oxford: Oxford University Press, 1999); see Larsen, The Slain God, 150-16o.

17 See for instance Davies, Anthropology. 
hence has not taken into account how Christianity evolves and shapes the ways in which people perceive their social environments elsewhere in the world.

Some research on global Pentecostalism has taken an interdisciplinary approach that combines theological and anthropological elements, such as the work of Allan Anderson and Jan-Åke Alvarsson. ${ }^{18}$ In their global outlook, the approach of such scholars resonates with this book's transcultural emphasis. The aim of the present volume, however, is to make the dialogue between anthropology and theology a central point to be reflected on and related to by all the authors in their respective chapters. This means that we do not only focus on theology and anthropology in the field of Pentecostalism, but take a wider approach to religion, including discussion of the ways a broader, enchanted worldview informs how people relate to the world and hence to religious categories and authorities.

This book is one of the results of more than a decade of Nordic Africanist cooperation between theology and anthropology, often taking shape in different projects like that led by Mika Vähäkangas, "Construction of African Christian Identity as a Dialogue between the Local and Global" (University of Helsinki, 2008-2011); the NOS-HS workshop series "Interpreting African Christianity: Anthropology and Theology in Dialogue" (2009-2010); "Looking for Wholeness in an Enchanted World: Healing, Prosperity and Ritual Action in African Charismatic/Pentecostal Churches" (Lund University, 2012-2018); and the Tomas Sundnes Drønen-led NOS-HS workshop series, "Religion and Development: Nordic Perspectives on Involvement in Africa" (vID University 2010-2013). All those contributing to this book have been involved in this cooperation in various ways. This Nordic Africanist cooperation has also spilled over to several doctoral dissertations being co-supervised across the disciplinary divide. Unlike the British crossovers in theology and anthropology, the Nordic version has concentrated on the study of African Christianity. This means that the focus has most often been on intercultural and inter-religious encounters and the emergence of different hybridities.

The aim of this book is to explore cross-pollination between anthropology and theology in the study of African lived Christianity. The ambition is to bring the two disciplines into dialogue in order to accentuate the ways in which they can enrich each other and, when integrated in specific studies, bring forth a profound understanding of African lived Christianity. It consists of three parts,

18 These scholars are linked to the GloPent network, which is a European Research Network on Global Pentecostalism committed to studying global Pentecostalism from an interdisciplinary perspective. See https://www.glopent.net/. 
the first of which deals with positionality in the study of African Christianity. Previous exchanges between anthropology and theology have proved that the researcher's position vis-à-vis the studied phenomenon - as well as her background culture and values - often finds itself the focus of the debate between these disciplines. This part will be followed by one that explores methods and approaches which attempt to build bridges between the disciplines or are located between them. Finally, the third part contains a selection of different cases in which anthropology and theology meet in the research of African lived Christianity.

Many of the chapters were presented at Lund University at the "African Lived Christianity - Faith, Ritual and Power" conference organized in March 2016 by the above-mentioned "Looking for Wholeness in an Enchanted World" project funded by the Swedish Research Council, Lund University Faculties of Humanities and Theology, and the Lund Mission Society. Joel Robbins' contribution was first presented as his inaugural lecture when being awarded an honorary doctorate at Lund University's Faculty of Theology in May 2016. His chapter deals directly with the relationship between anthropology and theology, addressing how new developments in both, namely the anthropology of Christianity and the world Christianity approach in theology, have opened up new possibilities of rapprochement and cooperation. Robbins' chapter ends with deliberations on the nature of positionality in these disciplines.

Frans Wijsen continues with a concrete case of debate on positionality in the study of African religions by analyzing the conversations that have taken place between different factions in the African Association for the Study of Religions. This is followed by Elina Hankela's chapter, which brings into the picture the multi-layered power relations found in empirical research endeavors wherein the researcher comes from a privileged background to study the underprivileged. Hankela positions herself staunchly in liberation theological traditions and represents, therefore, a research tradition with clear and open positionality and an agenda of change, both in academia and the researched communities. Part 1 closes with another deliberation on positionality by Galia Sabar who has researched both Christians and Jews in Africa. She ponders her varying positions as a researcher and a religiously active person in situations where her religious belonging, privileged background, and the blurring of religious boundaries make the terrain difficult to navigate.

Part 2 is opened by Karen Lauterbach, who discusses how anthropology and theology can enter into fruitful dialogue in the study of wealth and fakery in African charismatic Christianity. She argues that such a dialogue permits the researcher to move beyond studying the prosperity gospel as script, rather seeing it as an ideological and intellectual frontier in which the boundaries of 
what is considered legitimate wealth are contested and re-shaped. This is followed by Mika Vähäkangas' formulation of a theological methodology that makes use of ethnographical data in addition to the more traditional theological texts. This discussion draws on data from the study of the Kimbanguist church and suggests that resulting theological work of this nature would be able to communicate in both directions - theology and anthropology. Martina Prosén moves in a similar direction when exploring how Pentecostal praise and worship can empirically be studied as theology. Her methodological discussion is based on fieldwork in Nairobi churches. Niels Kastfelt's contribution offers a novel methodological approach to the study of the history of African Christianity in which he analyzes the soundscape of a Nigerian early zoth century village in order to interpret the relationship between traditional religion and Christianity. Part 2 concludes with Elias Bongmba's work that develops political theology for Africa in the conjuncture of the social sciences and theology.

Part 3 opens with a chapter by Stian Sørlie Eriksen, Tomas Sundnes Drønen, and Ingrid Løland. Their focus lies on studying identity construction among migrant African Christians in Norway at the nexus of multiple locations and identities. The topic of the tensions and fusions of identities is very common in the study of African Christianity, and Hans Olsson continues with that by analyzing the Pentecostals' relationship to Islam and politics in Zanzibar, Tanzania. Zanzibar Pentecostals are also largely a migrant community with origins in mainland Tanzania. Isabel Mukonyora takes us further into African Christian spirituality with political, social, and ecological repercussions by discussing Vapostori of Masowe's theological debates in which (post)colonialism, gender, and ecology are deeply intertwined. Rune Flikke's study, which follows, presents an analysis of faith in the African Instituted Church (AIC) wherein anthropology and theology play significant roles, offering the possibilities of a detailed interpretation of Zulu Zionist pneumatology. Here, healing and dealing with the spirit world are at the center of ritual activities. Continuing in the field of the AICs, Lotta Gammelin studies the role of gender in the narratives of illness and healing in Prophet Mpanji's church in Southern Tanzania. Here, an almost exclusively female clientele is being healed by the male prophet, leading to complex power relations of mutual dependency. Part 3 and the book conclude with Carl Sundberg's description of the difficulties produced in the ministry of the therapeutical centers of the Evangelical Church of Congo (Brazzaville) by generational change. Here, a healing activity combining African traditional herbalist elements with Christian ideas results in a ministry akin to many AICs but taking place in a historic reformed church. 


\section{References}

Balandier, George. "Messianismes et Nationalismes en Afrique Noire." Cahiers Internationaux de Sociologie 14 (1953): 41-65.

Bediako, Kwame. Theology and Identity: The Impact of Culture upon Christian Thought in the Second Century and in Modern Africa. Oxford: Regnum Books International, 1992.

Davies, Douglas. Anthropology and Theology. Oxford \& New York: Berg, 2002.

Douglas, Mary. In the Wilderness: The Doctrine of Defilement in the Book of Numbers. Sheffield: Sheffield Academic Press, 1993.

Douglas, Mary. Leviticus as Literature. Oxford: Oxford University Press, 1999.

Dozon, Jean-Pierre. La cause des prophètes: politique et religion en Afrique contemporaine. Paris: Seuil, 1995.

Evans-Pritchard, E.E. Nuer Religion. Oxford: Oxford University Press, 1956.

Ferrer, Jorge N. and Jacob H. Sherman. “Introduction." In The Participatory Turn: Spirituality, Mysticism, Religious Studies, edited by Jorge N. Ferrer and Jacob H. Sherman, 1-80. Albany, NY: SUNY Press, 2008.

Hanciles, Jehu. Beyond Christendom: Globalization, African Migration, and the Transformation of the West. Maryknoll, NY: Orbis Books, 2008.

Harris, Patrick and David Maxwell. "Introduction: The Spiritual in the Secular." In The Spiritual in the Secular: Missionaries and Knowledge about Africa, edited by Patrick Harris and David Maxwell, 1-29. Grand Rapids, Michigan: William B. Eerdmans Publishing Company, 2012.

Howell, Brian et al. "Faith in Anthropology: A Symposium on Timothy Larsen's The Slain God." The Cambridge Journal of Anthropology 34, no. 2 (2016): 140-152.

Larsen, Timothy. The Slain God:Anthropologists and the Christian Faith. Oxford: Oxford University Press, 2014.

Luzbetak, Louis. The Church and Cultures: New Perspectives in Missiological Anthropology. Maryknoll, NY: Orbis Books, 1989.

Munyika, Veikko. A Holistic Soteriology in an African Context. Pietermaritzburg: Cluster Publications, 2004.

Whiteman, Darrell. “One Significant Solution: How Anthropology Became the Number One Study for Evangelical Missionaries, Part II: Anthropology and Mission: The Incarnational Connection." International Journal of Frontier Missions 21, no. 2 (2004): 79-88.

Wild-Wood, Emma. "Afterword: Relocating Unity and Theology in the Study of World Christianity." In Relocating World Christianity: Interdisciplinary Studies in Universal and Local Expressions of the Christian Faith, edited by Joel Cabrita, David Maxwell and Emma Wild-Wood, 338-339. Leiden: Brill, 2017. 
Mika Vähäkangas and Karen Lauterbach - 9789004412255 Downloaded from Brill.com04/26/2023 01:05: 09PM via free access 